\title{
Chronic pain portrait: pain perception through the eyes of sufferers*
}

\author{
Retrato de dores crônicas: percepção da dor através do olhar dos sofredores
}

\begin{abstract}
Adrianna Loduca ${ }^{1,2}$, Barbara Maria Müller², Roberta Amaral ${ }^{2}$, Andrea Cristina Matheus da Silveira Souza ${ }^{2,4}$, Alessandra Focosi $^{1,2}$, Claudio Samuelian², Lin Tchia Yeng ${ }^{2,3}$, Marcia Batista ${ }^{1}$
\end{abstract}

${ }^{*}$ Received from Catholic University of São Paulo, São Paulo, SP, Brazil.

\section{ABSTRACT}

BACKGROUND AND OBJECTIVES: The literature mentions several factors influencing chronic pain onset or maintenance; however, it is known that such aspects cannot be generalized and universalized because studies state that socio-cultural differences interfere with pain perception. This study aimed at characterizing patients' perception of their pain and associated suffering as from the projective tool Portrait of Pain.

METHODS: This is an exploratory study with 150 patients with different chronic pains. They were evaluated as from sociodemographic variables related to pain and beliefs with regard to pain/suffering and proposed treatment (application of the Portrait of Pain). Information obtained from the Portrait of Pain was analyzed by the content analysis method. A single meeting was scheduled with mean duration of 60 minutes.

RESULTS: The study was made up of $64 \%$ of females, mean age of 52.5 years, $46 \%$ were married and $46 \%$ had not completed high school. Mean pain duration was 6 years (58\%). Drawings were grouped in 8 categories (scenes, monsters, objects, geometric shapes, irregular shapes and scribbles, whole human body, parts of the body and miscellaneous), evidencing that half of the subjects associated current suffering to other events with emotional impact and $87 \%$ expected to improve as from passive strategies.

CONCLUSION: There are few reports on the use of projective tools to evaluate and manage chronic pain. Results suggest that this resource could help characterizing the meaning of pain in

1. Catholic University of São Paulo, School of Human and Health Sciences, Psychology Course, Sáo Paulo, SP, Brazil.

2. School of Medicine University of São Paulo, Clinicas Hospital, Pain Group, São Paulo, SP, Brazil.

3. School of Medicine University of São Paulo, Clinicas Hospital, Pain Group, Department of Physiatry, Săo Paulo, SP, Brazil.

4. Institute of Infectology Emílio Ribas, Rehabilitation Department, São Paulo, SP, Brazil.

Submitted in November 25, 2013

Accepted for publication in February 19, 2014.

Conflict of interests: none.

Correspondence to:

Adrianna Loduca

Avenida Arnolfo Azevedo, 70 - Pacaembu

01236-030 São Paulo, SP, Brasil.

E-mail: grupodedor@gmail.com

(C) Sociedade Brasileira para o Estudo da Dor patients' lives and favor adhesion to proposed treatment. Further studies should come up to deepen the theme.

Keywords: Chronic pain, Evaluation of impact on health, Projective tool, Psychological evaluation.

\section{RESUMO}

JUSTIFICATIVA E OBJETIVOS: A literatura enumera vários fatores que influenciam na eclosão ou manutenção da dor crônica; entretanto, sabe-se que esses aspectos não podem ser generalizados e universalizados, pois estudos afirmam que as diferenças socioculturais interferem na percepção do quadro álgico. Este estudo teve como objetivo caracterizar a percepção que o paciente tem sobre sua dor e seu sofrimento associado a partir do recurso projetivo Retrato da Dor.

MÉTODOS: Trata-se de um estudo exploratório realizado com 150 pacientes com dor crônica de diversas etiologias. Eles foram avaliados a partir de variáveis sociodemográficas, relacionadas a dor e de crenças em relação a dor/sofrimento e ao tratamento proposto (aplicação do Retrato da Dor). As informaçôes obtidas no Retrato da Dor foram analisadas segundo o método de análise de conteúdo. Foi realizado um único encontro com duração média de 60 minutos.

RESULTADOS: A pesquisa foi composta por $64 \%$ de mulheres, com idade média de 52,5 anos, $46 \%$ eram casados e $46 \%$ tinham o $2^{\circ}$ grau incompleto. O tempo médio de convívio com a dor foi de 6 anos (58\%). Os desenhos foram agrupados em 8 categorias (cenas, monstros, objetos, formas geométricas, formas irregulares e rabiscos, corpo humano inteiro, partes do corpo e miscelânea), evidenciando-se que a metade dos sujeitos associava o sofrimento atual a outros eventos de impacto emocional, assim como $87 \%$ aguardava melhorar a partir de estratégias passivas.

CONCLUSÁO: Há poucos relatos do uso de instrumentos projetivos na avaliação e tratamento de dor crônica. Os resultados sugerem que esse recurso pode ajudar na caracterização do sentido da dor na vida do paciente e favorecer a adesáo ao tratamento proposto. Novos estudos devem surgir para maior aprofundamento do tema.

Descritores: Avaliação do impacto na saúde, Avaliação psicológica, Dor crônica, Instrumento projetivo.

\section{INTROCDUTION}

Chronic pain impacts life in different physical, psychological and social aspects, which are sometimes difficult to adjust and 
impair several areas of patients' lives ${ }^{1-10}$. These impacts result in uncertainties, fears, concerns and feeling of incapacity ${ }^{11-13}$, so persistence of pain globally impairs sufferers' lives.

When pain persists, in spite of therapeutic efforts, health professionals share with sufferers and their relatives the feeling of frustration, especially due to the fact of being unable to hasten healing. The attention should be turned to helping them adjusting to the resulting incapacity and to drug adverse effects ${ }^{14,15}$ which, when excessively used and for a long time, may decrease endorphin production by the body (pain blockers), thus increasing pain perception ${ }^{16}$. In this sense, understanding how patients interpret the impact of pain on their lives is a critical tool for the effectiveness of the treatment proposed by the multi or interdisciplinary team.

Specialized literature has studies explaining that culture may potentially interfere with pain, both from patients and professionals point of view, in different aspects of daily life. Each meaning is fruit of the influence of ideologies on health, quality of life and socioeconomic status ${ }^{17,18}$. It is noticed that the expression of suffering is made up by the sum of physical, emotional and social factors, so it cannot be translated just by quantifying pain frequency and intensity ${ }^{19}$. In addition, differences among ethnic and cultural groups evidence differences in language and meaning related to symptoms, opening space for the need to develop and validate local questionnaires ${ }^{20,21}$.

Professionals working for Brazilian Pain Centers have tried to validate international tools, but have also identified, as referred by international literature, the need to develop new resources to meet work demands of our teams and of the reality of the Brazilian population. Within this perspective, a study was carried out in $1998^{12}$, which has developed a projective tool called Portrait of Pain.

By that time, it was noticed that patients with the same pain diagnosis would not necessarily attribute the same meaning to their pain, which has encouraged the development of a tool were patients were asked to draw their physical discomfort, and in the sequence, questions were asked to help understanding the meaning of pain in the lives of patients. Since 2000 , as from this study ${ }^{12}$, a group of investigators is adopting the Portrait of Pain as a reference tool for psychological evaluation of patients admitted to the Pain Group, IOT, HCFMUSP.

While in Brazil, reports and meanings given by patients to their pain were valued, approximately in 2008, a movement appeared called PainSTORY, developed by European countries which were concerned with paying attention to the report and graphic expression of patients' pain. The investigation, counting on the collaboration of approximately 13 European countries, has gather data from 294 patients, throughout one year, and aimed at observing the impact of chronic pain on patients' lives. PainSTORY results have shown that pain had different meanings in patients' lives, reinforcing the importance of valuing individual reports and the richness of using other forms of pain expression, such as graphic production ${ }^{22}$. In 2010, a group of psychologists, in partnership with a pharmaceutical company, has developed a Portraits of Pain Handbook aiming at showing to health professionals that the meaning of pain for each patient was not restricted to clinical diagnosis. Our study was started by that time and now is being closed with the analysis of 150 Portraits of Pain under different aspects.

There are few reports in the international literature about the use of projective tools in psychological studies about chronic pain evaluation and management. Among those found, projective tools already existing in the area of Psychology were used, such as MMPI (Minnesota Multiphasic Personality Inventory), Rorchasch, Thematic Apperception Test (TAT) and Human Figure Drawing (HFD) ${ }^{23,24}$.

There is a gap with regard to the development of projective tools to help the evaluation of chronic pain patients. These evidences show the need for further resources to be used in the pain area to allow patients to express their distress in a freer and more creative way. Projective techniques require individuals to use characteristics of their personality, needs and life experiences to interpret ambiguous stimulations, which decreases the action of defense mechanisms and allows the access to contents not accessible by collaborator's awareness ${ }^{25}$. This study aimed at characterizing patients' perception of their pain and associated distress, by applying the Portrait of Pain projective tool.

\section{METHODS}

This is an exploratory study ${ }^{26}$ carried out with 150 patients with chronic pain of different etiologies indicated by the Pain Group, Institute of Orthopedics and Traumatology, Clinicas Hospital, School of Medicine, University of São Paulo, through a partnership established with the Catholic University of São Paulo. All patients starting treatment in the ambulatory between January 2010 and July 2013 were invited to participate. Exclusion criteria were presence of significant cognitive deficit and/or severe psychiatric disorders, in addition to refusal to participate in the investigation.

Investigation was focused on three groups of variables: sociodemographic (gender, age, marital status), pain-related (duration, pain numerical scale) and beliefs with regard to pain and to the multidisciplinary approach (application of Portrait of Pain). There has been only one interview with mean duration of 60 minutes.

Information obtained from the Portrait of Pain was analyzed according to the content analysis method ${ }^{27}$. Initially, a fluctuating reading of the material was carried out to identify themes and categories and after coding reports, investigators have tried to understand meanings that could arise from subjects' answers. Percentages were used to illustrate the frequency of answers, so no statistical treatment was applied since the focus was on enhancing the knowledge about the meaning of pain, characterizing the impact and how patients cope with their chronic pain, which has motivated the participation of a higher number of subjects ${ }^{26}$. 


\section{Description of material}

Pain numerical scale (NS): identifies the sensory quality of painful experience ${ }^{28}$. Patients are asked to classify their pain intensity according to a series of numbers varying from zero to 10 (or zero to 100) being that zero means "no pain" and 10 "the maximum possible pain".

Portrait of Pain: projective tool ${ }^{11,12,29}$ aiming at identifying patients' perception of their pain and associated distress. Patients are asked to imagine that their pain has a shape and then they are asked to draw it on a piece of paper. Colored pencils, graphite pencil and colored hydrographic pens are offered for the drawing. Patients are reminded that there is no right or wrong. After the drawing, an interview is carried out by means of seven questions aiming at broadening de understanding of pain.

This study was approved by the Ethics Committee, Catholic University of São Paulo, under n. 118/2005.

\section{RESULTS}

There has been predominance of females (64\%) and mean age was 52.5 years, prevailing the group from 31 to 55 years of age (61\% of participants), $46 \%$ were married and $46 \%$ had incomplete high school. With regard to time living with pain, most $(58 \%)$ had mean of six years and pain intensity was around 7.75 .

Portraits analysis allowed drawings to be grouped in eight categories: scenes, monsters, objects, geometric shapes, irregular shapes and scribbles, whole human body, parts of the body and miscellaneous. In addition to graphic representations, it is noticed the predominance of some colors. Most patients uses few colors prevailing black and gray $(70 \%)$ and when there are different colors, most common were red, brown and yellow complementing black and gray; the presence of colors such as green and blue was scarce.

With regard to the interview, names given by participants to their pain were distributed in three groups: physical, emotional and mixed. Few participants (4\%) have referred just emotional aspects (hope, dread, fear, concern, yearning). Most, approximately $67 \%$, have called pain by adjectives and nouns including both physical discomfort and unpleasant emotions (snake, vicious pain, rollercoaster, boomerang) and $29 \%$ have stressed sensory aspects (throbbing, beating, jumping, burning). As to pain age, $44 \%$ of patients gave to drawing ages corresponding to the time they were living with pain, while $30 \%$ gave ages above the time of its onset. When mentioning living with pain, predominant answer (44.8\%) was that it was bad (terrible, horrible or lousy).

With regard to beliefs about what could improve discomfort, $85 \%$ mentioned passive approaches, that is, they considered that just external interventions with drugs or health professionals' assistance, especially the physician, could revert the situation:

- 40\%: only physicians and drugs could relieve their pain;

- 19\%: interdisciplinary team or proposed treatment could change the situation, but patient did not believe that could contribute to such process;

- $17 \%$ did not believe than someone or something could treat pain;

- 9\%; have attributed to God the only possibility of reaching the "miracle of healing".

When asked whether pain could be associated to other situations as bad as or worse than living with pain:

- $50 \%$ have related to other events of emotional impact, especially situations of mourning and losses: $66 \%$ death of beloved ones and $22 \%$ problems with loving relationships (betrayals and separations);

- $24 \%$ have mentioned events of physical impact: remembrance of other pains or acute and chronic diseases;

- $17 \%$ have stated that this was the worst event ever happened to their lives.

\section{DISCUSSION}

The prevalence of females reinforces Brazilian literature data on the frequency of pain among this population ${ }^{10}$, and mean age is in line with other Brazilian studies ${ }^{11,14}$, showing that the highest incidence of pain occurs in the productive population, thus significantly intefering with labor situation.

Further discussing identified drawing categories, we give below illustrations which allow characterizing each category: SCENES: Patients making analogies with situations close to current suffering. The drawing of a 36 years old female with pelvic pain (NS=7) is a good illustration. She referred that her pelvic pain could be compared to burning with boiling water (Figure 1), being that heat and burning sensations are pain descriptors commonly found in the literature ${ }^{30}$.

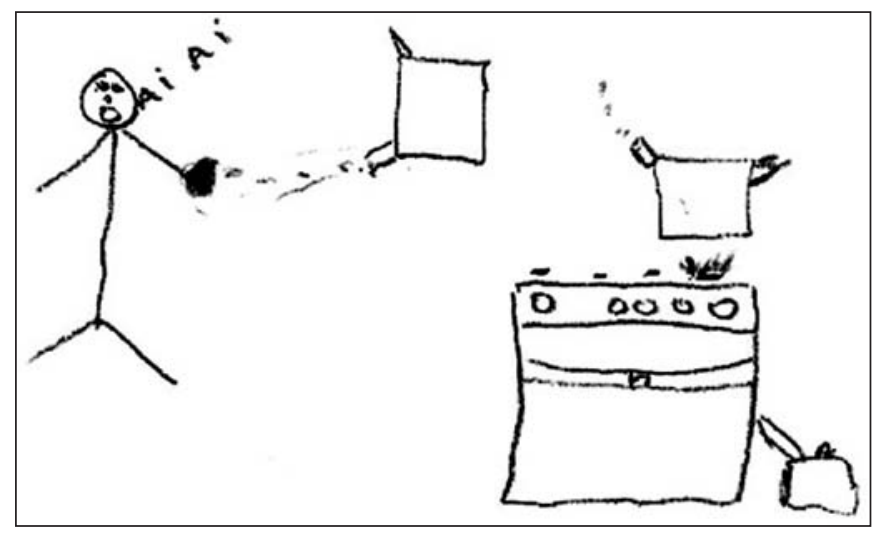

Figure 1. Example of scene

MONSTERS: representations (Figure 2) which scare, portraying the torture caused by pain in daily life. A 74 years old male with low back pain stated living with his pain for 40 years (NS=7). He said that it was very bad, it was evil, sadism. He also mentioned that he felt he was fighting against his own body what illustrates the pattern of rejection with regard to pain $^{12}$, being this a moment when patients measure forces to fight against pain. 


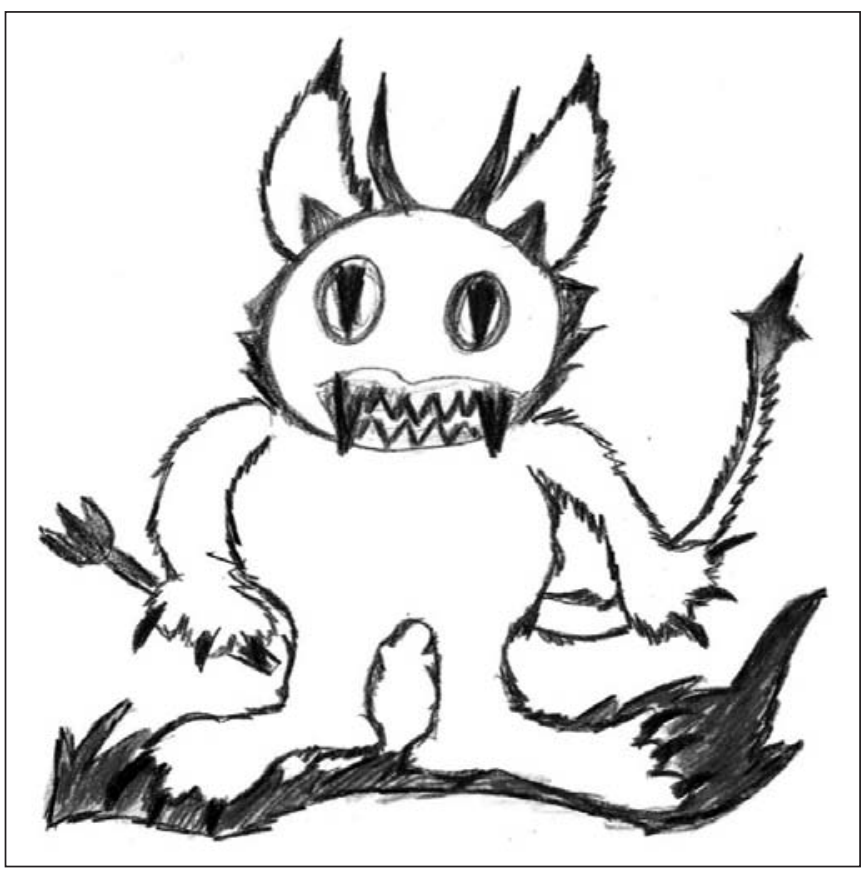

Figure 2. Example of monster

OBJECTS: drawings of objects or figures expressing physical malaise and evidencing sensory pain aspects (something that irradiates, pulses, weighs or burns). Figure 3 was drawn by a 31 years old male with myofascial pain syndrome $(\mathrm{NS}=9)$ who referred that his pain gave him the sensation of being stabbed.

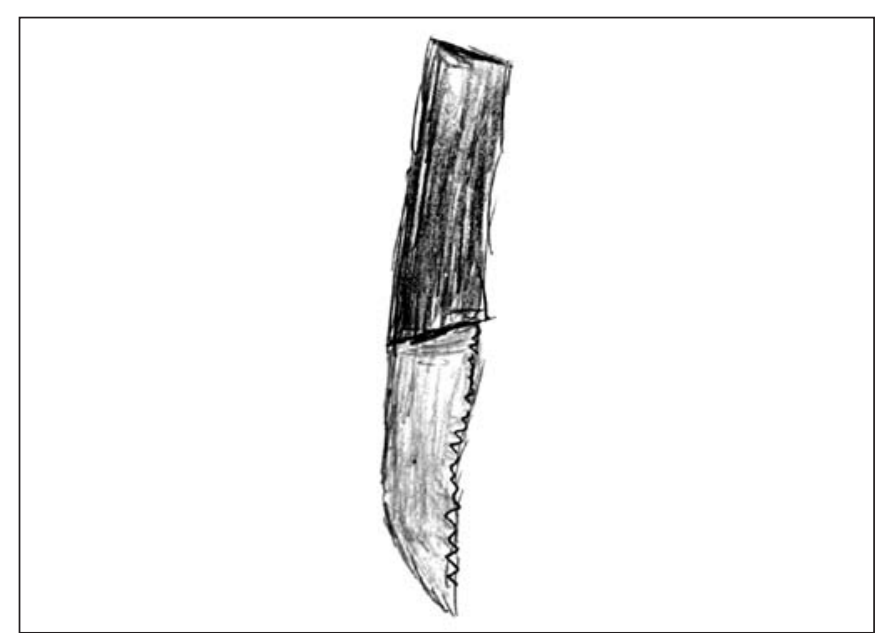

Figure 3. Example of object

GEOMETRIC SHAPES: among them, circular shapes were the most commonly drawn, which may indicate emphasis on the sensation of weight or remaining in a vicious cycle: pain-stresspain. Figure 4 was drawn by a 36 years old female with complex regional pain syndrome $(\mathrm{NS}=8)$. She reported that her pain could improve if people would believe it is real, she felt herself alone and discredited. It is noticed in this case that the heaviest weight was related to lack of credibility and support from relatives and from the closest social media which, in turn, has expanded her suffering to beyond physical discomfort. Although reports like this are common in the clinical practice, there are authors who discuss the impact of chronic pain on the family, however without considering patients' sensation of discredit.

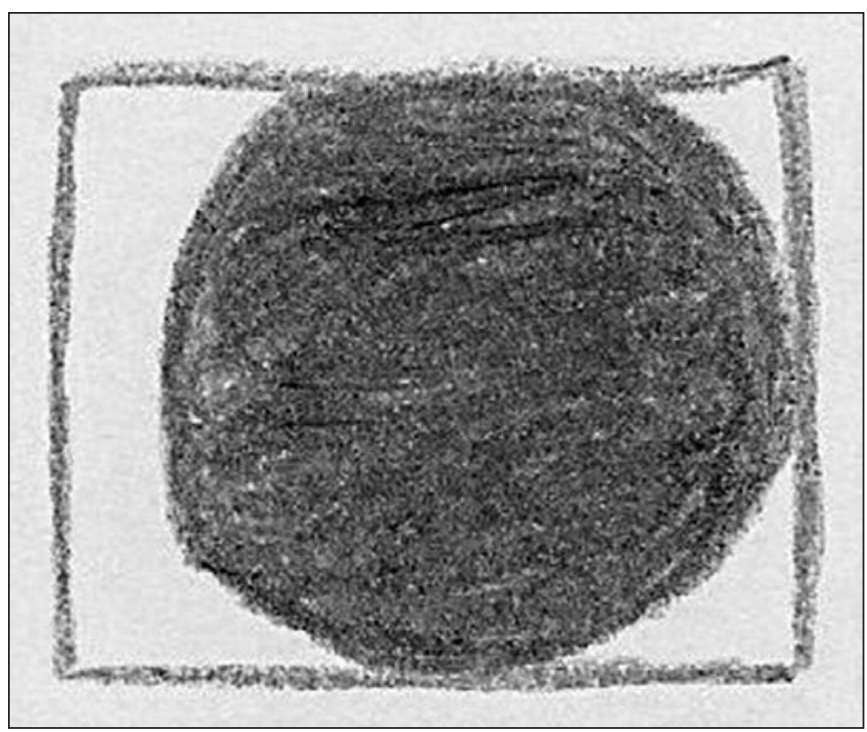

Figure 4. Example of geometric shape

IRREGULAR SHAPES AND SCRIBBLES: these are more primitive drawings (regressed) which show motor discharge, probably impulsivity and/or anger. This is the case of figure 5 , drawn by a 29 years old female with cervicogenic headache $(\mathrm{NS}=4)$, who referred having drawn a blot to express the bad sensation caused by pain, that is, possibly the strong tracing evidences discharge of anger and frustration ${ }^{32}$. Others have drawn waves as if they wished to represent sensory stimulation circuit, explaining that they are trying to cope with the problem in a rational way, not allowing much space for emotions. It is noticed that drawings may illustrate the discharge of strong emotions or represent sensory pain aspects.

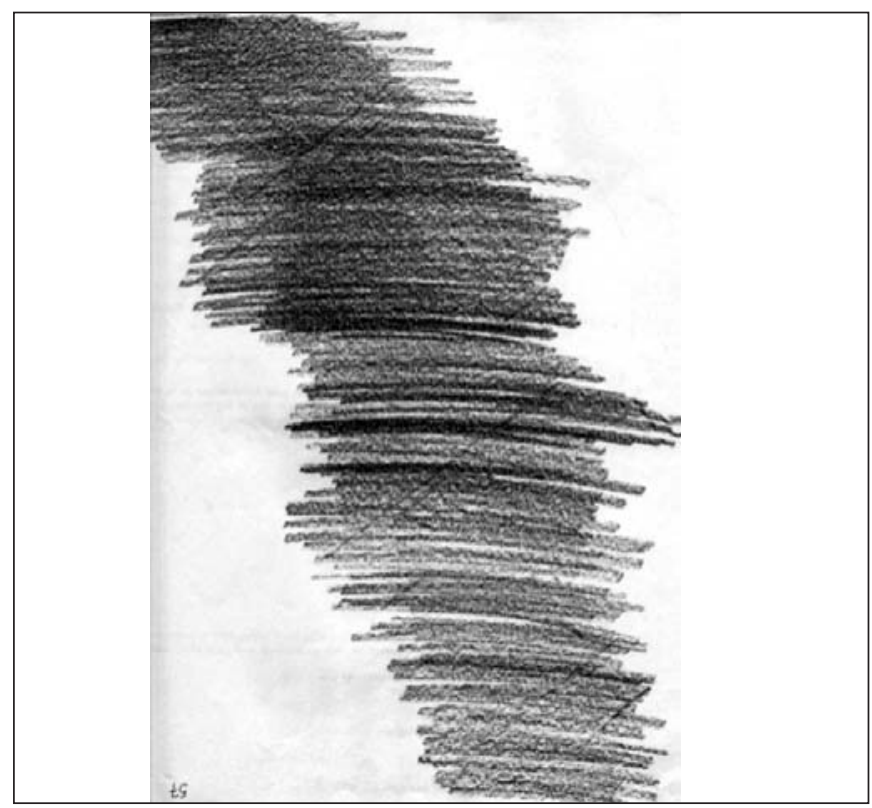

Figure 5. Example of irregular shape and scribble 
WHOLE BODY: self-portraits or representations of body scheme showing that pain affects them completely although, very often, this pain is affecting just one or some parts of the body. Figure 6 is a drawing of a 25 years old female with immobility syndrome $(\mathrm{NS}=10)$. Both patient's drawing and report made clear that pain affected her whole body in a very severe way, as if her identity would have been taken by pain, which evidences the chaotic pattern of living with pain, where there is little or no differentiation between Myself and Pain ${ }^{12}$.

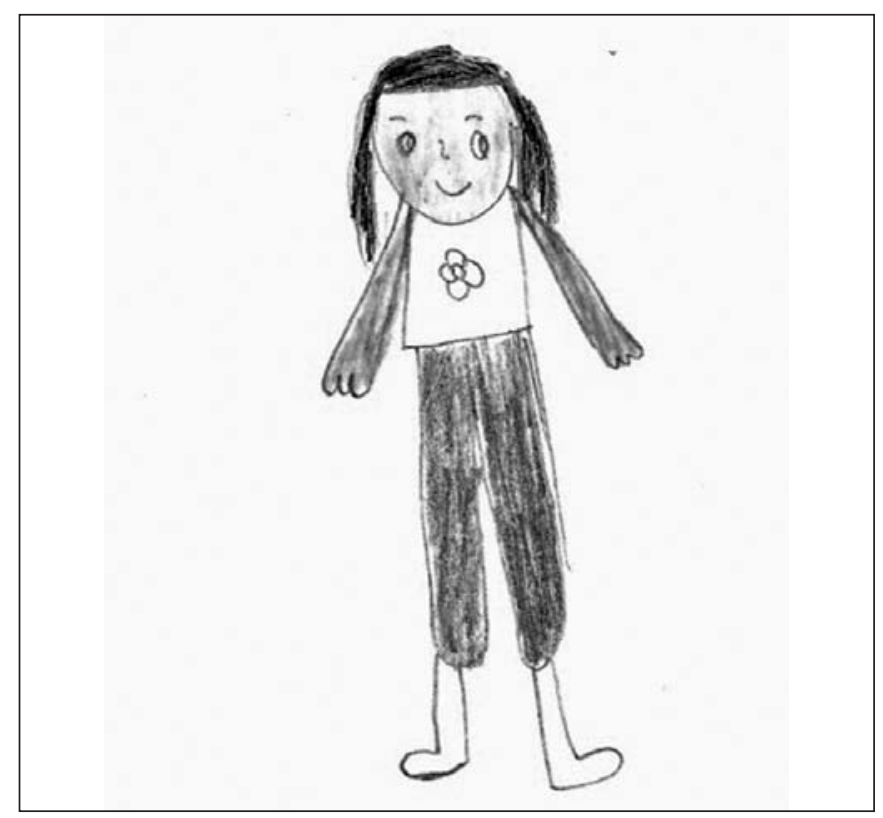

Figure 6. Example of whole body

PARTS OF THE BODY: drawings of parts of the body that ache, revealing that the focus of interest of the patient is turned to uncomfortable regions, as stressed in figure 7 , drawn by a 40 years old female with phantom pain

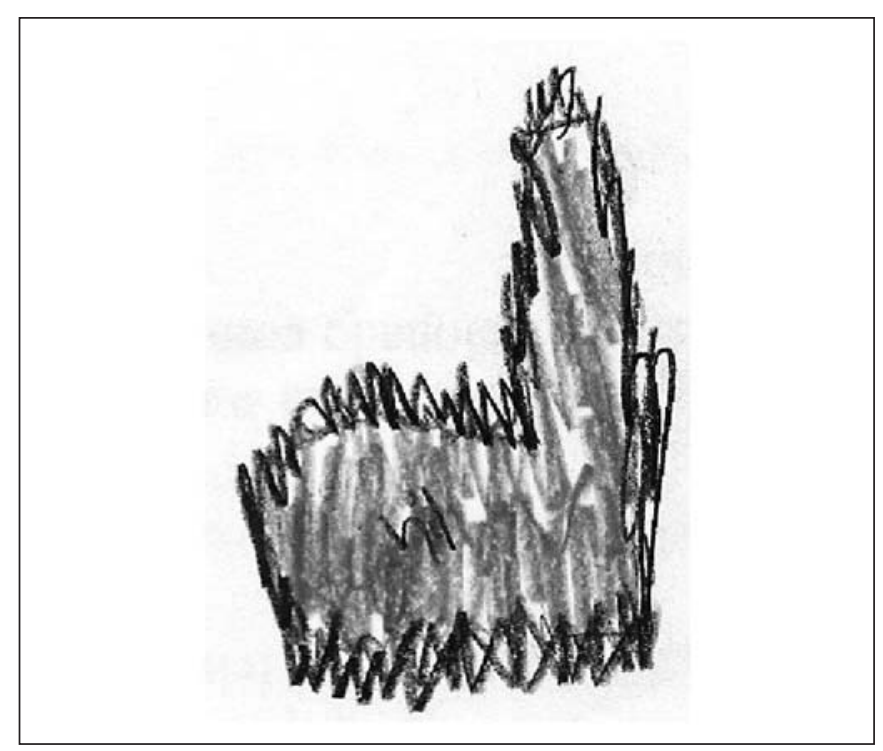

Figure 7. Example of parts of the body
$(\mathrm{NS}=7)$. Here one can notice the need to help the patient to broaden her body perception, thus being able to use the potential of parts of the body which were not affected by pain, as well as preventing the use of body compensation schemes to impair other body areas. The pattern of dependence when living with pain prevails when patient's interests are oriented by pain ${ }^{12}$.

MISCELLANEOUS: subjects who made drafts that could not be grouped in any identified category were allocated to this group.

As to drawing colors, black and gray, or colors associated by patients with pain intensity have prevailed. Few participants have used colors they liked and when they used them they made clear their effort to neutralize the discomfort with some stimuli which would give a sensation of well-being. Although there is a psychological study ${ }^{33}$ about the use of colors on drawings, the meaning attributed to this variable was not considered in this study.

With regard to the interview it has been observed that most names given to pain characterized both physical discomfort and unpleasant emotions patients felt with regard to pain; this reinforces IASP definition of pain which highlights the importance of pain being treated from the biopsychosocial perspective ${ }^{34}$. As to age given to the time they were living with pain, it calls the attention that patients have given ages older than the pain onset, which shows the trend to perpetuate suffering and the need to help them leave the position of victims. With regard to beliefs ${ }^{35}$ about what could improve pain, passive approaches have prevailed showing the need for psycho-educative programs to further involve patients with the proposed treatment, broadening the understanding of the problem and the learning of how can they help the effectiveness of the proposed treatment, strengthening coping resources and sense of efficacy ${ }^{36}$.

When asked whether they would associate their pain with other situations as bad as or worse than living with pain, half the participants have referred other events of emotional impact, especially mourning, which reinforces the importance of psychological assistance to this population to prevent psychological variables to help the maintenance or worsening of pain or to impair adhesion to proposed pain treatment. Psychology is broadening its space in the area of health in multi and interdisciplinary teams due to the known efficacy of its interventions and to the multidimensional character of the illness process ${ }^{37}$.

Our results have shown that the application of the Portrait of Pain helps patients express their suffering beyond physical suffering, trying to understand it within the biography of each patient ${ }^{31}$. This tool minimizes individual rationalization mechanisms, allowing the collection of important information and also the recognition of the influence of psychological factors on pain perception ${ }^{30}$. Sometimes, the interview mobilizes patients' emotions and makes them perceive or recognize the demand for psychological assistance ${ }^{12,30}$. 


\section{CONCLUSION}

There are few reports in the international literature on the use of projective tools by psychological studies about chronic pain evaluation and treatment, and results found in the analysis have shown the difficulty to generalize information, that is, they reinforce the subjective and peculiar character of each patient's experience.

It is also important to recognize that, although the multidisciplinary approach is the best treatment indicated for chronic pain, patients still look for immediate solutions. They long for invasive procedures or drugs that may place them in a passive role with regard to well-being recovery.

This study has shown that emotional aspects play important role in the way individuals interpret and use their own resources to deal with pain, so their report should not be overlooked. Report analysis should be considered an element to be taken into consideration by health professionals in chronic pain centers to evaluate patients for further definition of therapeutic approaches. Other studies should be carried out to broaden and deepen evidences of our investigation.

\section{REFERENCES}

1. Bates MS, Edwards WT, Anderson KO. Ethnocultural influences on variation in chronic pain perception. Pain. 1993;52(1):101-12.

2. Wall PD, Melzack R, (editors). Textbook of pain. $4^{\text {th }}$ ed. Edinburgh: Churchill Livingstone; 1999. 1504p.

3. Jakobsson U, Klevsgård R, Westergren A, Hallberg IR. Old people in pain: a comparative study. J Pain Symptom Manage. 2003;26(1):625-36.

4. Keefe FJ, Rumble ME, Scipio CD, Giordano LA, Perri LM. Psychological aspects of persistent pain: current state of the science. J Pain. 2004;5(4):195-211

5. Linton SJ. A review of psychological risk factors in back and neck pain. Spine. 2000;25(9):1148-56.

6. McBeth J, Macfarlane GJ, Hunt IM, Silman AJ. Risk factors for persistent chronic widespread pain: a community-based study. Rheumatology. 2001;40(1):95-101.

7. Manek NJ, MacGregor AJ. Epidemiology of back disorders: prevalence, risk factors, and prognosis. Curr Opin Rheumatol. 2005;17(2):134-40.

8. Buer N, Linton SJ. Fear-avoidance beliefs and catastrophizing: occurrence and risk factor in back pain and ADL in the general population. Pain. 2002;99(3):485-91

9. Menzel NN. Psychosocial factors in musculoskeletal disorders. Crit Care Nurs Clin North Am. 2007;19(2):145-53.

10. Kreling MC, da Cruz DA, Pimenta CA. [Prevalence of chronic pain in adult workers]. Rev Bras Enferm. 2006;59(4):509-13. Portuguese.

11. Yeng LT, Teixeira MJ. Tratamento multidisciplinar dos doentes com dor crônica. Rev Prática Hosp. 2004;35:28-32.

12. Loduca A, Samuelian C. Avaliação psicológica: do convívio com dores crônicas à adesão ao tratamento na clínica de dor. In: Alves Neto O, Cost CM, Siqueira JTT,
Teixeira MJ, (editores). Dor, princípios e prática. 1a ed. Porto Alegre, Artmed; 2009. 382-97p.

13. Szumita RP, Szumita PM, Just N. Understanding and managing patients with chronic pain. Oral Maxillofac Surg Clin North Am. 2010;22(4):481-94.

14. Ferreira KA, Siqueira SR, Teixeira MJ. Características demográficas, da dor e do tratamento dos pacientes atendidos em centro multidisciplinar de dor. Cad Saúde Colet. 2008;16(3):449-70.

15. Turk DC. Biopsychosocial perspective on chronic pain. In: Gatchel RJ, Turk DC, (editors). Psychological approaches to pain management: a practitioner's handbook. New York: Guilfold; 1996. 3-32p.

16. Wells C, Nown G. In pain? A self-help guide for chronic pain sufferers, London Optima Book; 1993. 1-50p.

17. Campbell LC, Andrews N, Scipio C, Flores B, Feliu MH, Keefe FJ. Pain coping in Latino populations. J Pain. 2009;10(10):1012-9.

18. Shavers VL, Bakos A, Sheppard VB. Race, ethnicity, and pain among the U.S. adult population. J Health Care Poor Underserved. 2010;21(1):177-220.

19. McWhinney IR. An introduction to family medicine. New York, Oxford: Oxford University Press; 1981. 219p.

20. Goldman J, Conrad DF, Ley C, Halperin D, de la Luz Sanchez M, Villacorta R, et al. Validation of a Spanish language dyspepsia questionnaire. Dig Dis Sci 2002;47(3):624-40.

21. Urnes J, Johannessen T, Farup PG, Lydersen S, Petersen H. Digestive symptoms and their psychosocial impact: validation of a questionnaire. Scand J Gastroenterol. 2006;41(9):1019-27

22. O'Brien T, Breivik H. The impact of chronic pain--European patients' perspective over 12 months. Scand J Pain. 2012;3(1):23-9.

23. Villemor-Amaral AE, Pasqualini-Casado L. A cientificidade das técnicas projetivas em debate. Psico USF. 2006;11(2):185-93.

24. Panek PE, Skowronski JJ, Wagner EE. Differences on the projective hand test among chronic pain patients reporting three different pain experiences. J Pers Assess. 2002;79(2):235-42.

25. Nunes MF, Okino ET, Noce MA, Jardim-Maran ML. Interesses profissionais: perspectivas teóricas e instrumentos de avaliaçāo. Aval Psicol. 2008;7(3):403-14.

26. Triviños ANS. Introduçấo à pesquisa em ciências sociais: a pesquisa qualitativa em educação. São Paulo: Atlas; 1987. 175p.

27. Bardin L. Análise de conteúdo. 3a ed. Lisboa: Ediçōes; 2004. 70p.

28. Melzack R, Katz J. The McGill pain questionnaire: appraisal and current status. In Turk DC, Melzack R. Handbook of pain assessment. $2^{\text {nd }}$ ed. New York: Guilford; 2001. 35-52p.

29. Loduca A, Samuelian C. Avaliaçáo psicológica do doente com dor. In: Teixeira MJ Braum JL, Yeng LT, Marquez JO (editores). Dor-contexto interdisciplinar, Curitiba: Editora Maio; 2002. 191-204p.

30. Lin CP, Kupper AE, Gammaitoni AR, Galer BS, Jensen MP. Frequency of chronic pain descriptors: implications for assessment of pain quality. Eur J Pain. 2011;15(6):628-33.

31. West C, Usher K, Foster K, Stewart L. Chronic pain and the family: the experience of the partners of people living with chronic pain. J Clin Nurs. 2012;21(23-24):3352-60.

32. Hammer EF. A Técnica Projetiva do Desenho da Casa-Árvore-Pessoa: interpretação do conteúdo. In: Hammer EF. (Org.). Aplicaçōes clínicas dos desenhos projetivos. São Paulo: Casa do Psicólogo; 1991.

33. Van Klock OL. Interpretação psicológica de desenhos: três estudos. São Paulo: Pioneira; $1968.179 \mathrm{p}$

34. Classification of chronic pain: Descriptions of chronic pain syndromes and definitions of pain terms. Seattle (WA): IASP Press; 1994.

35. McCracken LM, Carson JW, Eccleston C, Keefe FJ. Acceptance and change in the context of chronic pain. Pain. 2004;109(1-2):4-7.

36. Asghari A, Nicholas MK. Pain self-efficacy beliefs and pain behaviour: a prospective study. Pain. 2001;94(1):85-100.

37. Capitấo CG, Scortegagna SA, Baptista MN. A importância da avaliação psicológica na saúde. Aval Psicol. 2005;4(1):75-82. 